\title{
Penerapan Metode TOPSIS sebagai Rekomendasi Pemilihan Wisata (Studi Kasus: Kabupaten Cilacap)
}

\author{
Tri Mega Anggraeni ${ }^{1 *}$, Gita Fadila Fitriana ${ }^{2 * *}$, Cepi Ramdani ${ }^{3 * * *}$ \\ * Teknik Informatika, Institut Teknologi Telkom Purwokerto \\ ** Rekayasa Perangkat Lunak, Institut Teknologi Telkom Purwokerto \\ *** Sistem Informasi, Institut Teknologi Telkom Purwokerto \\ 17102047@ittelkom-pwt..ac.id ${ }^{1}$, gita@ittelkom-pwt..ac.id ${ }^{2}$, cepi@ittelkom-pwt..ac.id ${ }^{3}$
}

\begin{tabular}{l} 
Article Info \\
\hline Article history: \\
Received 2021-08-18 \\
Revised 2021-11-17 \\
Accepted 2021-12-04 \\
\hline
\end{tabular}

Keyword:

Agile Development, Decision Support System, TOPSIS,

Tourist

\begin{abstract}
Indonesian people have made vacation activities a primary need so that vacations are not just travelling. Now people are starting to travel longer, farther, and more often. When making tourist visits, domestic tourists are faced with many choices of destinations in the city. Cilacap City is one of the cities with many tourist attractions, in this city requires the selection of tourist objects according to the interests and interests of each tourist. So, it takes a recommendation system for the user to achieve the goal. The user can choose the desired tourist destination more effectively. The application of tourist recommendations in Cilacap City aims to overcome the problems that occur to tourists. This application uses a Decision Support System using the TOPSIS method with the development of the Agile methodology. The result implementingon of the topstopicshod in Cilacap City are the recommendation for Mount Srandil tourism by 78\%, Momongan Island by $77 \%$, Soesilo Soedarman Museum by $74 \%$, Karang Bolong Fort by $71 \%$ and Widarapayung Beach by $63 \%$. So, the recommended result is Srandil Mountain tourism. This application also tests the function software's functionality Blackbox method with $100 \%$ results, where users, namely tourists, can understand the application's functionality.
\end{abstract}

\section{Pendahuluan}

Kabupaten Cilacap merupakan daerah terluas di Jawa Tengah yang mempunyai aset wisata alam yang cukup menjanjikan, banyaknya objek wisata yang tersedia menyebabkan wisatawan bingung untuk memilih objek wisata mana saja yang akan dikunjungi[1]. Berdasarkan data Badan Pusat Statistik (BPS) pada tahun 2020 tercatat jumlah pengunjung pada tempat wisata di Kabupaten Cilacap mencapat 270.908 pengunjung. Masih banyak calon wisatawan yang tidak mengetahui objek wisata yang ada di Kabupaten Cilacap. Saat ini juga belum ada media yang memberikan rekomendasi untuk wisatawan, khususnya wisatawan yang akan berkunjung ke objek wisata yang berada di Kabupaten Cilacap. Dalam penelitian Eva Zuraidah, untuk memudahkaan calon wisatawan dalam mengetahui lebih banyak tempat wisata dengan informasi yang cukup akurat serta rekomendasi tempat wisata yang sesuai maka dibutuhkan sebuah sistem yang dapat memberikan rekomendasi dan memuat informasi yang akurat yang dapat diakses secara online[2]. Sistem pendukung keputusan digunakan untuk mendukung solusi pemecahan masalah, pengambilan keputusan merupakan bentuk pemilihan dari banyaknya alternatif yang tersedia[3]. Tersedia beberapa metode yang dapat digunakan untuk diimplementasikan pada sistem pendukung keputusan seperti metode Analytic Hierarchy Process (AHP), Simple Additive Weighting (SAW), Technique For Order Preference by Similarity to Ideal Solution (TOPSIS) dan lain-lain[4].

Beberapa penelitian yang menggunakan metode TOPSIS, Eka Aprilia dan Sri Ipnuwati[1] "Sistem Pendukung Keputusan Pemilihan Wisata Air Terjun Unggulan dengan Menggunakan Metode TOPSIS di Kabupaten Pesawaran". Dengan menggunakan 5 kriteria yaitu: view, jarak, waktu 
tempuh, biaya masuk, fasilitas. Alternatif yang digunakan sebanyak 5. Penelitian yang dilakukan oleh Avriana Indarwasti, Barizana S, dan Prottasof G Kodu[5] "Sistem Pendukung Keputusan Pemilihan Tempat Kuliner di Depok dengan TOPSIS". Dengan menggunakan 5 kriteria seperti: rasa, variasi menu, waktu operasional, area, fasilitas. Alternatif yang digunakan sebanyak 3 .

Berdasarkan uraian diatas, dengan adanya suatu sistem yang dapat memberikan rekomendasi wisata dapat menjadi solusi. Dalam penelitian ini membangun sebuah sistem yang dapat memberikan rekomendasi pemilihan wisata menggunakan metode TOPSIS. Metode TOPSIS dipilih karena alternatif yang terpilih mempunyai jarak terdekat dengan solusi ideal positif dan memiliki jarak terjauh dengan solusi ideal negatif sehingga alternatif yang terpilih tersebut mempunyai kombinasi jarak yang baik[5], metode TOPSIS juga mempunyai konsep yang sederhana sehingga mudah dimengerti. Adapun dalam pengembangannya sistem menggunakan bahasa pemrograman PHP dan framework Laravel. Sistem yang dibuat menggunakan 5 kriteria untuk menentukan rekomendasi, kriteria tersebut yaitu: harga, jarak, fasilitas, rating, dan minat pengguna. Jarak pada sistem ini menggunakan titik koordinat pengguna secara otomatis ketika pengguna sedang menggunakan sistem.

\section{Metode Penelitian}

Pada penelitian ini menggunakan beberapa tahapan yang dilakukan seperti berikut:

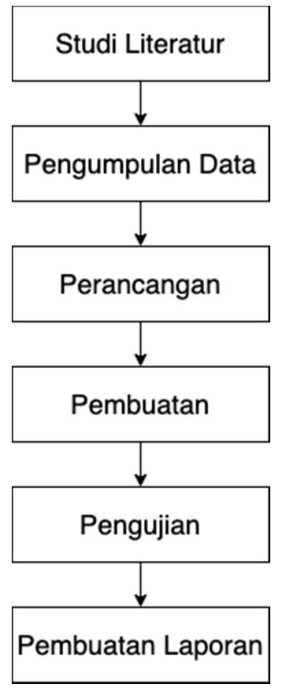

Gambar 1. Alur Penelitian

\section{A. Studi Literatur}

Studi literatur merupakan proses pengumpulan data dengan cara mempelajari dan memahami apa saja yang dibutuhkan dan mencari referensi yang berhubungan dengan data yang diperlukan. Pada penelitian ini studi pustaka dilakukan pada situs website dan aplikasi terpercaya yang membahas mengenai wisata Cilacap.

\section{B. Pengumpulan Data}

Tahap pengumpulan data dilakukan dengan melakukan observasi terhadap Badan Pusat Statistik (BPS) Kabupaten Cilacap dan aplikasi "Wisata Cilacap" untuk mendapatkan data objek wisata yang tercatat dan juga fasilitas yang ada pada objek-objek wisata. Untuk data berupa titik koordinat masing-masing objek wisata didapatkan dari Google Maps, survei secara langsung juga dilakukan dengan mendatangi tempat wisata untuk melengkapi informasi objek wisata yang masih kurang lengkap. Dari data tersebut peneliti menggunakan 5 kriteria berupa jarak, harga , fasilitas, rating, dan minat pengguna.

\section{Perancangan}

Pada tahap ini dilakukan perancangan dan pendefinisian sistem untuk mengetahui ruang lingkup aplikasi yang akan dikembangkan. Perancangan dilakukan dengan membuat beberapa rancangan:

1) use case diagram yang merupakan gambaran scenario pengguna dan perilaku pengguna terhadap sistem.

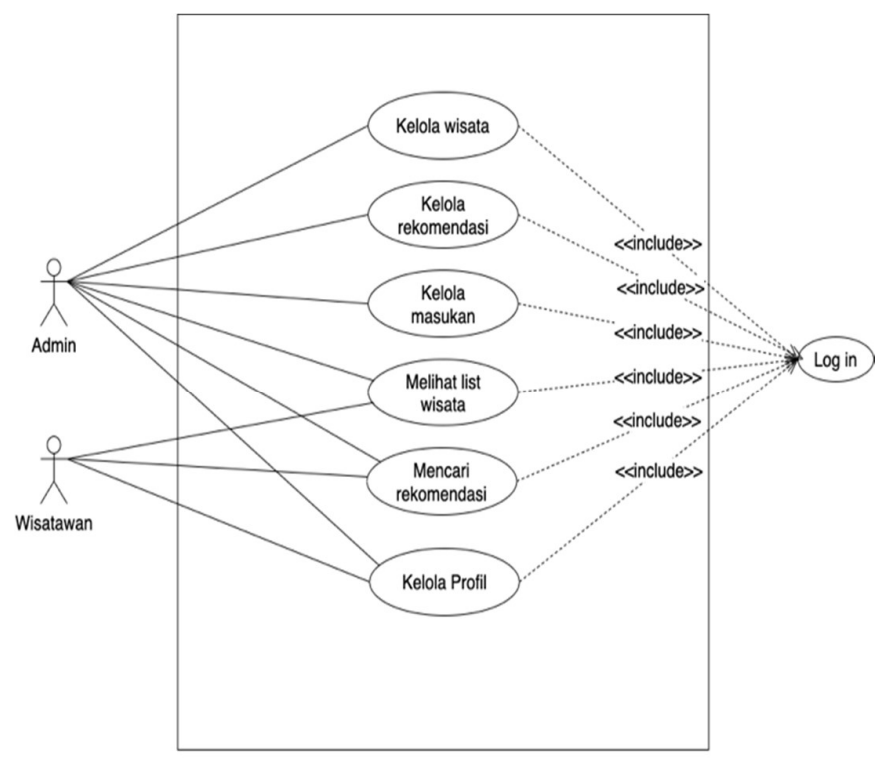

Gambar 2. Use Case Diagram

Dalam sistem terdapat 2 jenis pengguna yaitu admin dan wisatawan. Admin dapat melakukan beberapa aksi seperti kelola wisata, kelola rekomendasi, kelola masukan, melihat isi wisata, mencari rekomendasi, dan kelola profil. Sedangkan wisatawan dapat melakukan beberapa aksi seperti melihat list wisata, mencari rekomendasi, dan kelola profil. 
2) Perancangan antarmuka atau user interface bertujuan agar pembuatan antarmuka sistem lebih tertata[6], antarmuka yang digunakan alangkah baiknya menarik dan mudah dipahami oleh pengguna. Berikut merupakan antarmuka untuk sistem yang dibuat.

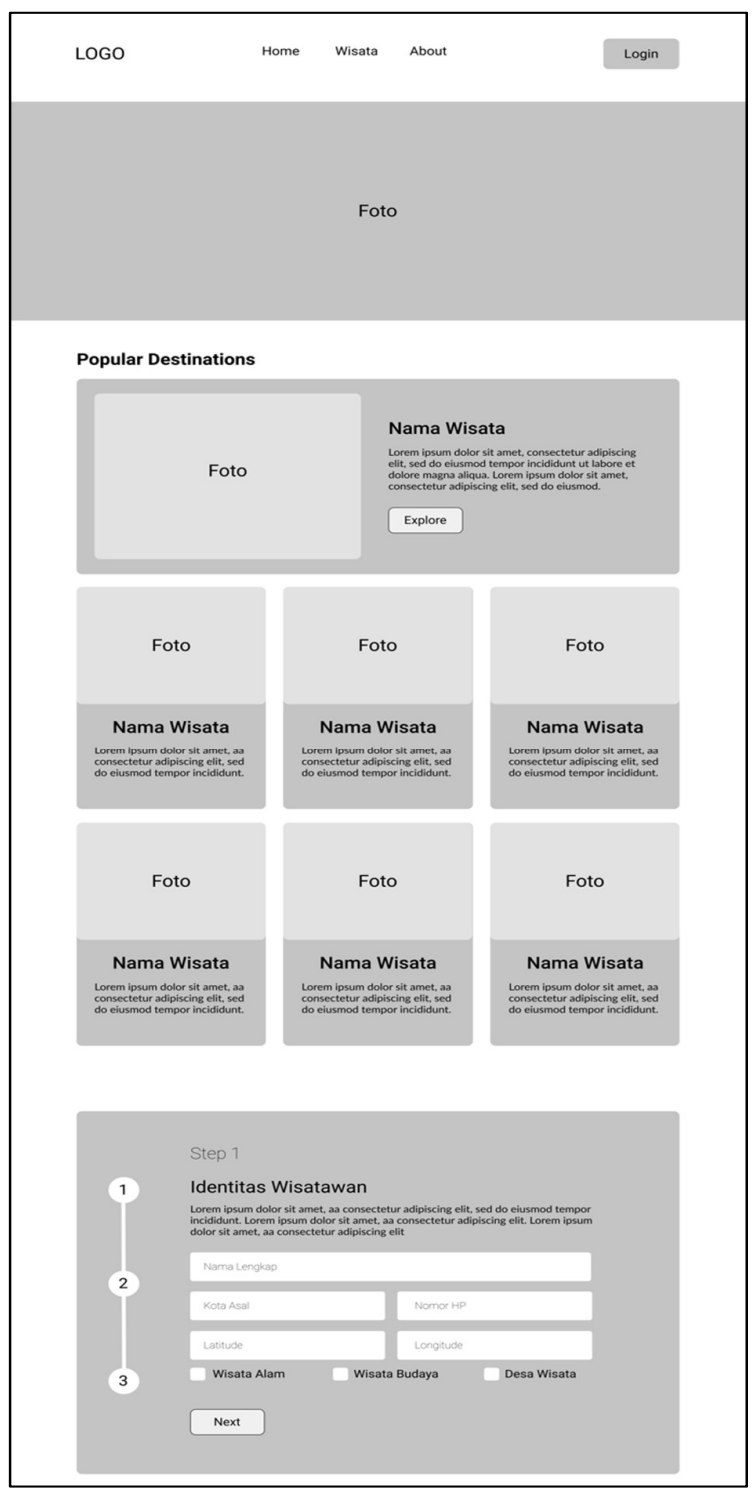

Gambar 3. Rancangan Antarmuka

Pada halaman antarmuka terdapat menu utama yaitu home, wisata, dan about. Halaman ini akan muncul pertama kali ketika pengguna mengakses website.

3) Perancangan basis data, pada penelitian ini dilakukan menggunakan MySQL Database yang terdiri dari 7 tabel diantaranya tabel wisata, tabel jarak_wisata, tabel rating_wisata, tabel bobot, tabel gambar, tabel user, dan tabel user_rekomendasi.
D. Pembuatan

Tahap pembuatan sistem dilakukan pengimplementasian perancangan yang sudah dibuat dengan menggunakan bahasa pemrograman PHP dan framework Laravel serta menerapkan metode TOPSIS untuk memberikan rekomendasi kepada wisatawan.

\section{E. Pengujian}

Setelah sistem selesai dibuat maka dilakukan tahap pengujian menggunakan metode Black Box testing, metode pengujian ini digunakan untuk menemukan ketidaksesuaian pada sistem secara fungsionalnya saja[7]. Pengujian dilakuukan oleh 48 responden, dimana jumlah responden tersebut diukur berdasarkan metode Slovin, metode ini digunakan untuk menentukan sampel pada suatu populasi[8] dengan perhitungan sebagai berikut.

$$
\begin{aligned}
& n=\frac{270908}{1+270908 \times{\frac{15^{2}}{100}}^{2}} \\
& n=\frac{270908}{270909 \times 0,0025} \\
& n=\frac{270908}{6095,4525} \\
& n=44,45
\end{aligned}
$$

Keterangan:

$n=$ Besaran sampel

$\mathrm{N}=$ Besaran populasi

$e=$ Nilai kritis (batas ketelitian) yang diinginkan (persen kelonggaran ketidaktelitian karena kesalahan penarikan sampel).

Besaran populasi $(\mathrm{N})$ yang digunakan merupakan jumlah wisatawan pada Kabupaten Cilacap pada tahun 2020 dengan margin error yang peneliti gunakan yaitu $15 \%$.

Adapun daftar pengujian yang dilakukan menggunakan metode Black Box sebagai berikut:

TABEL I

DAFTAR PENGUJIAN

\begin{tabular}{|l|l|}
\hline Nama Pengujian & \multicolumn{1}{|c|}{ Detail Pengujian } \\
\hline Akses hosting & $\begin{array}{l}\text { Mengakses skripsimega.xyz pada } \\
\text { web browser }\end{array}$ \\
\hline Log in akun & Memasukkan username dan password \\
\hline $\begin{array}{l}\text { Mengakses } \\
\text { wisata }\end{array}$ & $\begin{array}{l}\text { Memilih salah satu wisata yang } \\
\text { disajikan }\end{array}$ \\
\hline Rating wisata & Menambahkan rating dan komentar \\
\hline $\begin{array}{l}\text { Rekomendasi } \\
\text { wisata }\end{array}$ & $\begin{array}{l}\text { Memasukkan nama, email, kota asal, } \\
\text { nomor HP, latitude dan longitude, } \\
\text { memilih jenis wisata, memilih } \\
\text { kategori prioritas (harga, jarak, } \\
\text { fasilitas, rating, dan tipe) }\end{array}$ \\
\hline List wisata & Memilih menu wisata pada menu bar \\
\hline Tambah feedback & Menambahkan komentar atau saran \\
\hline
\end{tabular}




\begin{tabular}{|c|c|}
\hline Dashboard & $\begin{array}{l}\text { Menekan tombol halaman dashboard } \\
\text { admin }\end{array}$ \\
\hline Tambah wisata & $\begin{array}{l}\text { Menambahkan objek wisata yang } \\
\text { baru }\end{array}$ \\
\hline Edit wisata & $\begin{array}{l}\text { Mengubah detail objek wisata yang } \\
\text { sudah ada }\end{array}$ \\
\hline Hapus wisata & $\begin{array}{l}\text { Menghapus objek wisata yang sudah } \\
\text { ada }\end{array}$ \\
\hline Hitung bobot & $\begin{array}{l}\text { Memasukkan bobot sesuai kategori } \\
\text { yang ada }\end{array}$ \\
\hline $\begin{array}{l}\text { Detail } \\
\text { perhitungan }\end{array}$ & Menampilkan detail perhitungan \\
\hline $\begin{array}{l}\text { Hapus list } \\
\text { rekomendasi }\end{array}$ & $\begin{array}{l}\text { Menghapus list rekomendasi yang } \\
\text { sudah ada }\end{array}$ \\
\hline Bobot jarak & $\begin{array}{l}\text { Memasukkan titik koordinat } \\
\text { pengguna (latitude dan longitude) dan } \\
\text { menampilkan hasilnya }\end{array}$ \\
\hline List rating wisata & $\begin{array}{l}\text { Menampilkan daftar rating wisata } \\
\text { yang sudah ada }\end{array}$ \\
\hline Tambah rating & Menambahkan rating pada wisata \\
\hline Edit rating & Mengubah rating yang sudah ada \\
\hline Hapus rating & Menghapus rating yang sudah ada \\
\hline Tambah gambar & $\begin{array}{l}\text { Menambahkan gambar pada galeri } \\
\text { wisata }\end{array}$ \\
\hline Hapus gambar & $\begin{array}{l}\text { Menghapus gambar yang sudah ada } \\
\text { pada galeri wisata }\end{array}$ \\
\hline Feedback & $\begin{array}{l}\text { Menampilkan feedback yang } \\
\text { diberikan oleh pengguna }\end{array}$ \\
\hline Hapus feedback & $\begin{array}{l}\text { Menghapus feedback yang diberikan } \\
\text { oleh pengguna }\end{array}$ \\
\hline Log out & Melakukan $\log$ out akun \\
\hline
\end{tabular}

\section{F. Pembuatan Laporan}

Pembuatan laporan dilakukan untuk memaparkan secara detail proses penelitian yang dilakukan dari awal hingga akhir dengan mengikuti kaidah-kaidah penulisan yang sudah ditentukan.

\section{HASIL DAN PEMBaHASAN}

Bagian ini berisi mengenai hasil dan pembahasan penerapan metode TOPSIS sebagai rekomendasi pemilihan wisata sesuai dengan rancangan yang sudah dibuat.

\section{A. Hasil Implementasi}

Hasil implementasi berisi mengenai penerapan dari perancangan yang sudah dilakukan sebelumnya, adapun hasil implementasi dari penelitian ini sebagai berikut:

1) Implementasi Sistem

Implementasi sistem merupakan tahap menerjemahkan perancangan kedalam bahasa yang dapat dimengerti oleh mesin. Tahap implementasi antarmuka dilakukan berdasarkan rancangan yang telah dibuat sebelumnya. Pada halaman utama terdapat 3 menu yaitu menu home, wisata, dan about. Pengguna juga dapat melakukan log in

pada halaman ini. Halaman utama menampilkan beberapa destinasi popular dan destinasi random untuk memberikan referensi wisata bagi pengguna. Pada halaman ini juga terdapat fitur rekomendasi, pengguna dapat memasukkan nama, email, kota asal, nomor HP, titik koordinat akan terisi otomatis, memilih jenis wisata yang diminati. Selanjutnya pengguna diminta untuk mengisikan harga, jarak, fasilitas, rating, dan tipe menggunakan kategori (tidak penting, penting, sangat penting) lalu akan dihasilkan 5 rekomendasi wisata yang cocok sesuai masukkan pengguna. Berikut ini merupakan hasil implementasi sistem:

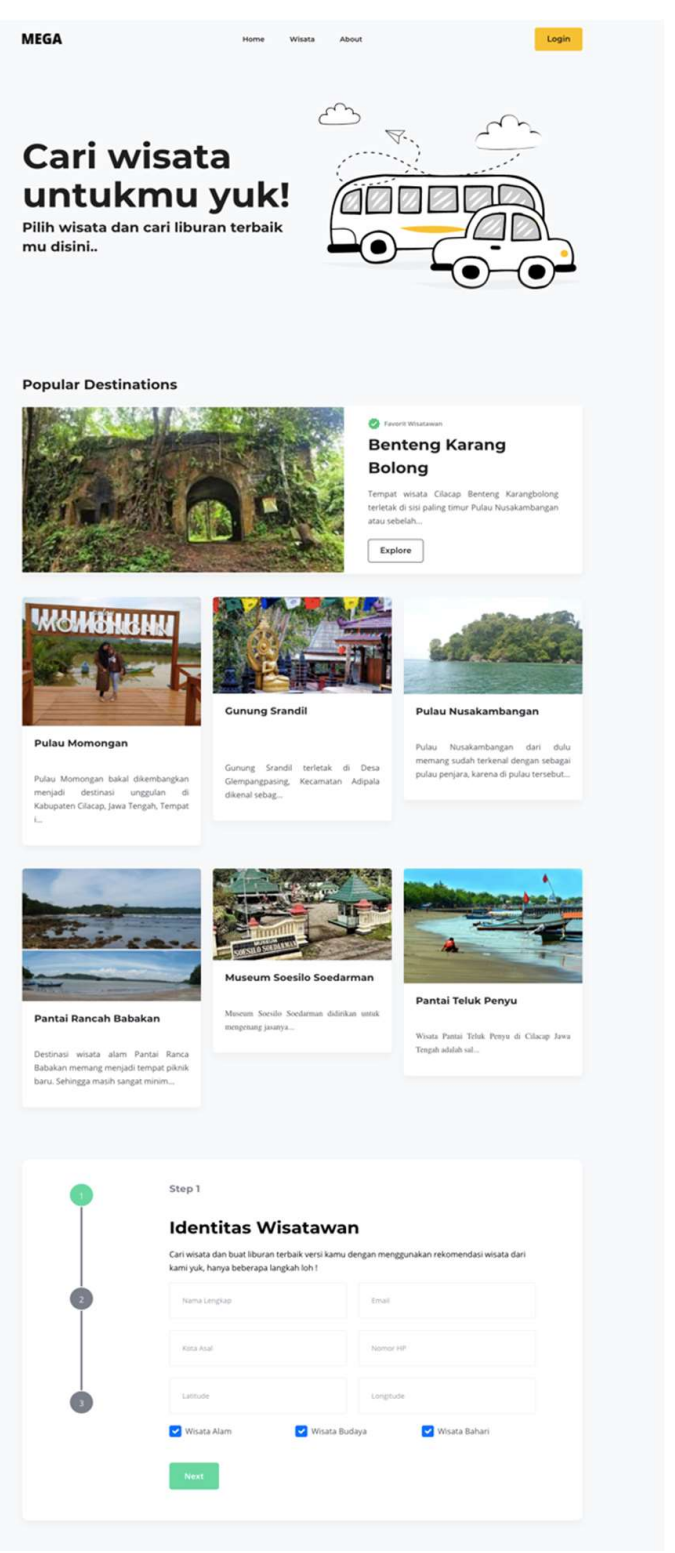

Gambar 5. Implementasi Sistem 
2) Implementasi Metode TOPSIS

Pada sistem, perhitungan ini terletak pada halaman admin menu "Rekomendasi" dan pada list rekomendasi terdapat "Lihat Detail". Data sampel yang akan dibandingkan dengan perhiutngan manual menggunakan data yang sama dan menunjukan hasil akhir perhitungan yang sama antara perhitungan sistem dengan perhitungan manual. Berikut merupakan langkah perhitungan manual yang dilakukan.

1. Penentuan kriteria

Kriteria atau parameter yang digunakan pada sistem yaitu Jarak (C1), Harga (C2), Rating (C3), Fasilitas (C4), dan Minat (C5).

TABEL II

MATRIKS KRITERIA

\begin{tabular}{|l|l|c|c|c|c|c|}
\hline \multirow{2}{*}{$\begin{array}{l}\text { Alter } \\
\text { natif }\end{array}$} & \multirow{2}{*}{ Objek Wisata } & \multicolumn{5}{|c|}{ Kriteria } \\
\cline { 3 - 7 } A1 & Pantai Teluk Penyu & 0.6 & 0.83 & 0.44 & 1 & 1 \\
\hline A2 & Pantai Widarapayung & 0.83 & 0.83 & 0.33 & 1 & 1 \\
\hline A3 & Pantai Sodong & 0.82 & 0.78 & 0.22 & 1 & 1 \\
\hline A4 & Pantai Karang Pakis & 0.78 & 0.83 & 0.33 & 0.6 & 1 \\
\hline A5 & $\begin{array}{l}\text { Pantai } \\
\text { Nusakambangan }\end{array}$ & 0.58 & 0 & 0.56 & 0.6 & 1 \\
\hline A6 & $\begin{array}{l}\text { Pantai Ketapang } \\
\text { Indah }\end{array}$ & 0.83 & 0.83 & 0.33 & 0.4 & 1 \\
\hline A7 & Curug Cimendaway & 0 & 0.87 & 0.22 & 0.4 & 1 \\
\hline A8 & Hutan Payau & 0.71 & 0.62 & 0.22 & 0.8 & 1 \\
\hline A9 & $\begin{array}{l}\text { Hutan Mangroove } \\
\text { Kampung Laut }\end{array}$ & 0.6 & 0.33 & 0.22 & 1 & 1 \\
\hline A10 & Pantai Cemara Sewu & 0.75 & 0.67 & 0.22 & 1 & 1 \\
\hline A11 & Air Panas Cipari & 0.38 & 0.75 & 0 & 0.6 & 1 \\
\hline A12 & Pulau Momongan & 0.75 & 0.83 & 1 & 0 & 1 \\
\hline A13 & Selok View & 0.82 & 0.78 & 0.33 & 1 & 1 \\
\hline A14 & Rancah Babakan & 0.24 & 0.83 & 0.56 & 0.2 & 1 \\
\hline A15 & Kemit Forest & 0.49 & 0.33 & 0.22 & 1 & 1 \\
\hline A16 & Goa Masigitsela & 0.12 & 1 & 0 & 0.6 & 1 \\
\hline A17 & Pantai Jetis & 0.77 & 0.83 & 0.33 & 1 & 1 \\
\hline A18 & Benteng Pendem & 0.56 & 0.75 & 0.33 & 0.8 & 1 \\
\hline A19 & Gunung Srandil & 0.83 & 1 & 0.67 & 0.6 & 1 \\
\hline A20 & $\begin{array}{l}\text { Museum Soesilo } \\
\text { Soedarman }\end{array}$ & 1 & 0.83 & 0.56 & 0.6 & 1 \\
\hline A21 & Benteng Klingker & 0.55 & 0.75 & 0.44 & 0.2 & 1 \\
\hline A22 & $\begin{array}{l}\text { Benteng Karang } \\
\text { Bolong }\end{array}$ & 0.57 & 0.75 & 1 & 0.2 & 1 \\
\hline A23 & $\begin{array}{l}\text { Desa Wisata Karang } \\
\text { Banar }\end{array}$ & 0.78 & 0.87 & 0 & 0.8 & 1 \\
\hline
\end{tabular}

2. Nilai bobot dari setiap kriteria

Bobot didefinisikan dengan nilai $1=$ tidak penting, 2 = penting, dan $3=$ sangat penting. Sebagai sampel dimasukan nilai bobot sebagai berikut:

TABEL III BOBOT MASUKAN

\begin{tabular}{|c|c|c|c|c|}
\hline Harga & Jarak & Minat & Fasilitas & Rating \\
\hline 3 & 3 & 1 & 3 & 2 \\
\hline
\end{tabular}

3. Mempersiapkan matriks keputusan

Pada data yang didapatkan, data tersebut mempunyai karakteristik masing-masing berdasarkan tipe kriteria. Sebagai contoh jarak mempunyai karakteristik semakin dekat jaraknya maka semakin tinggi nilainya. Sedangkan pada rating, semakin kecil rating makan nilai nya akan semakin kecil. Sehingga perlu dilakukan normailisasi menggunakan metode Linear Weightage. Normalisasi inilah yang menjadi pembeda dengan 2 penelitian sebelumnya, karena pada penelitian tersebut menggunakan kriteria yang berkarakteristik sama sehingga cukup menggunakan normalisasi yang ada dalam metode TOPSIS saja. Berikut cara melakukan normalisasi data menggunakan metode Linear Weightage pada alternatif pantai Teluk Penyu (A1).

4. Menghitung nilai kriteria jarak $(\mathrm{C} 1)$

$$
\begin{aligned}
r_{\max } & =\frac{\max -w s}{\max -\min } \\
& =\frac{47.04-24.75}{47.04-10.17}=0.6
\end{aligned}
$$

5. Menghitung nilai kriteria harga $(\mathrm{C} 2)$

$$
\begin{aligned}
r_{\max } & =\frac{\max -w s}{\max -\min } \\
& =\frac{30000-5000}{30000-0}=0.83
\end{aligned}
$$

6. Menghitung nilai kriteria rating (C3)

$$
\begin{aligned}
r_{\min } & =\frac{w s-\min }{\max -\min } \\
& =\frac{4.3-3.9}{4.8-3.9}=0.44
\end{aligned}
$$

7. Menghitung nilai kriteria fasilitas (C4)

$$
\begin{aligned}
r_{\min } & =\frac{w s-\min }{\max -\min } \\
& =\frac{6-1}{6-1}=1
\end{aligned}
$$

Keterangan:

$r_{\text {max }}=$ nilai kriteria bertipe threshold maximum

$r_{\text {min }}=$ nilai kriteria bertipe threshold minimum

$\max =$ nilai tertinggi pada kriteria

$m i x=$ nilai terendah pada kriteria

$w s=$ nilai yang dicari normalisasinya

8. Menghitung nilai kriteria minat (C5)

Pada perhitungan nilai minat dianggap sama rata, karena minat nantinya digunakan untuk menampilkan objek wisata terpilih berdasarkan tipe atau jenis wisata.

Normalisasi dilakukan hingga kriteria ke-23 sehingga menghasilkan data pada Tabel IV berikut. 
TABEL IV

MATRIKS NORMALISASI WEIGHTAGE

\begin{tabular}{|l|c|c|c|c|c|}
\hline \multirow{2}{*}{$\begin{array}{l}\text { Altern } \\
\text { atif }\end{array}$} & \multicolumn{5}{|c|}{ Kriteria } \\
\cline { 2 - 6 } A1 & C1 & C2 & C3 & C4 & C5 \\
\hline A2 & 0.6 & 0.83 & 0.44 & 1 & 1 \\
\hline A3 & 0.83 & 0.83 & 0.33 & 1 & 1 \\
\hline A4 & 0.78 & 0.83 & 0.33 & 0.6 & 1 \\
\hline A5 & 0.58 & 0 & 0.56 & 0.6 & 1 \\
\hline A6 & 0.83 & 0.83 & 0.33 & 0.4 & 1 \\
\hline A7 & 0 & 0.87 & 0.22 & 0.4 & 1 \\
\hline A8 & 0.71 & 0.62 & 0.22 & 0.8 & 1 \\
\hline A9 & 0.6 & 0.33 & 0.22 & 1 & 1 \\
\hline A10 & 0.75 & 0.67 & 0.22 & 1 & 1 \\
\hline A11 & 0.38 & 0.75 & 0 & 0.6 & 1 \\
\hline A12 & 0.75 & 0.83 & 1 & 0 & 1 \\
\hline A13 & 0.82 & 0.78 & 0.33 & 1 & 1 \\
\hline A14 & 0.24 & 0.83 & 0.56 & 0.2 & 1 \\
\hline A15 & 0.49 & 0.33 & 0.22 & 1 & 1 \\
\hline A16 & 0.12 & 1 & 0 & 0.6 & 1 \\
\hline A17 & 0.77 & 0.83 & 0.33 & 1 & 1 \\
\hline A18 & 0.56 & 0.75 & 0.33 & 0.8 & 1 \\
\hline A19 & 0.83 & 1 & 0.67 & 0.6 & 1 \\
\hline A20 & 1 & 0.83 & 0.56 & 0.6 & 1 \\
\hline A21 & 0.55 & 0.75 & 0.44 & 0.2 & 1 \\
\hline A22 & 0.57 & 0.75 & 1 & 0.2 & 1 \\
\hline A23 & 0.78 & 0.87 & 0 & 0.8 & 1 \\
\hline
\end{tabular}

9. Membuat matriks keputusan yang ternormalisasi, untuk menghasilkan nilai yang sebanding, maka dilakukan normalisasi terhadap matriks keputusan. Berikut hasil normalisasi matriks keputusan.

TABEL V

MATRIKS BOBOT

\begin{tabular}{|l|c|c|c|c|c|}
\hline \multirow{2}{*}{ Nilai } & $\mathrm{X}[1]$ & $\mathrm{X}[2]$ & $\mathrm{X}[3]$ & $\mathrm{X}[4]$ & $\mathrm{X}[5]$ \\
\cline { 2 - 6 } & 3.21 & 3.68 & 2.17 & 3.54 & 4.8 \\
\hline
\end{tabular}

TABEL VI

MATRIKS TERNORMALISASI

\begin{tabular}{|l|c|c|c|c|c|}
\hline \multirow{2}{*}{$\begin{array}{l}\text { Altern } \\
\text { atif }\end{array}$} & \multicolumn{5}{|c|}{ Kriteria } \\
\cline { 2 - 6 } & C1 & C2 & C3 & C4 & C5 \\
\hline A1 & 0.19 & 0.23 & 0.2 & 0.28 & 0.21 \\
\hline A2 & 0.26 & 0.23 & 0.15 & 0.28 & 0.21 \\
\hline A3 & 0.26 & 0.21 & 0.1 & 0.28 & 0.21 \\
\hline A4 & 0.24 & 0.23 & 0.15 & 0.17 & 0.21 \\
\hline A5 & 0.18 & 0 & 0.26 & 0.17 & 0.21 \\
\hline A6 & 0.26 & 0.23 & 0.15 & 0.11 & 0.21 \\
\hline A7 & 0 & 0.24 & 0.1 & 0.11 & 0.21 \\
\hline A8 & 0.22 & 0.17 & 0.1 & 0.23 & 0.21 \\
\hline A9 & 0.19 & 0.09 & 0.1 & 0.28 & 0.21 \\
\hline A10 & 0.23 & 0.18 & 0.1 & 0.28 & 0.21 \\
\hline A11 & 0.12 & 0.2 & 0 & 0.17 & 0.21 \\
\hline A12 & 0.23 & 0.23 & 0.46 & 0 & 0.21 \\
\hline A13 & 0.26 & 0.21 & 0.15 & 0.28 & 0.21 \\
\hline A14 & 0.07 & 0.23 & 0.26 & 0.06 & 0.21 \\
\hline A15 & 0.15 & 0.09 & 0.1 & 0.28 & 0.21 \\
\hline
\end{tabular}

\begin{tabular}{|l|c|c|c|c|c|}
\hline A16 & 0.04 & 0.27 & 0 & 0.17 & 0.21 \\
\hline A17 & 0.24 & 0.23 & 0.15 & 0.28 & 0.21 \\
\hline A18 & 0.17 & 0.2 & 0.15 & 0.23 & 0.21 \\
\hline A19 & 0.26 & 0.27 & 0.31 & 0.17 & 0.21 \\
\hline A20 & 0.31 & 0.23 & 0.26 & 0.17 & 0.21 \\
\hline A21 & 0.17 & 0.2 & 0.2 & 0.06 & 0.21 \\
\hline A22 & 0.18 & 0.2 & 0.46 & 0.06 & 0.21 \\
\hline A23 & 0.24 & 0.24 & 0 & 0.23 & 0.21 \\
\hline
\end{tabular}

10. Menghitung matriks ternormalisasi terbobot

Perhitungan matriks ternormalisasi terbobot dihasilkan dari matriks yang sudah dinormalisasi dikalikan dengan bobot.

TABEL VII

MATRIKS TERNORMALISASI TERBOBOT

\begin{tabular}{|l|c|c|c|c|c|}
\hline \multirow{2}{*}{$\begin{array}{l}\text { Altern } \\
\text { atif }\end{array}$} & \multicolumn{5}{|c|}{ Kriteria } \\
\cline { 2 - 6 } & $\mathbf{C 1}$ & $\mathbf{C 2}$ & $\mathbf{C 3}$ & $\mathbf{C 4}$ & C5 \\
\hline A1 & 0.57 & 0.69 & 0.4 & 0.28 & 0.21 \\
\hline A2 & 0.78 & 0.69 & 0.3 & 0.28 & 0.21 \\
\hline A3 & 0.78 & 0.63 & 0.2 & 0.28 & 0.21 \\
\hline A4 & 0.72 & 0.69 & 0.3 & 0.17 & 0.21 \\
\hline A5 & 0.54 & 0 & 0.52 & 0.17 & 0.21 \\
\hline A6 & 0.78 & 0.69 & 0.3 & 0.11 & 0.21 \\
\hline A7 & 0 & 0.72 & 0.2 & 0.11 & 0.21 \\
\hline A8 & 0.66 & 0.51 & 0.2 & 0.23 & 0.21 \\
\hline A9 & 0.57 & 0.27 & 0.2 & 0.28 & 0.21 \\
\hline A10 & 0.69 & 0.54 & 0.2 & 0.28 & 0.21 \\
\hline A11 & 0.36 & 0.6 & 0 & 0.17 & 0.21 \\
\hline A12 & 0.69 & 0.69 & 0.92 & 0 & 0.21 \\
\hline A13 & 0.78 & 0.63 & 0.3 & 0.28 & 0.21 \\
\hline A14 & 0.21 & 0.69 & 0.52 & 0.06 & 0.21 \\
\hline A15 & 0.45 & 0.27 & 0.2 & 0.28 & 0.21 \\
\hline A16 & 0.12 & 0.81 & 0 & 0.17 & 0.21 \\
\hline A17 & 0.72 & 0.69 & 0.3 & 0.28 & 0.21 \\
\hline A18 & 0.51 & 0.6 & 0.3 & 0.23 & 0.21 \\
\hline A19 & 0.78 & 0.81 & 0.62 & 0.17 & 0.21 \\
\hline A20 & 0.93 & 0.69 & 0.52 & 0.17 & 0.21 \\
\hline A21 & 0.51 & 0.6 & 0.4 & 0.06 & 0.21 \\
\hline A22 & 0.54 & 0.6 & 0.92 & 0.06 & 0.21 \\
\hline A23 & 0.72 & 0.72 & 0 & 0.23 & 0.21 \\
\hline
\end{tabular}

11. Menghitung solusi ideal positif dan solusi ideal negative Solusi ideal positif diperoleh dari jumlah nilai terbaik yang ada pada setiap atribut, sedangkan solusi ideal negatif diperoleh dari nilai terendah yang ada pada setiap atribut.

TABEL VIII

SOLUSI IDEAL POSITIF

\begin{tabular}{|c|c|}
\hline Positif & A+ \\
\hline Y1+ & 0.81 \\
\hline Y2+ & 0.72 \\
\hline Y3+ & 0.92 \\
\hline Y4+ & 0.78 \\
\hline Y5+ & 0.19 \\
\hline
\end{tabular}


TABEL IX

SOLUSI IDEAL NEGATIF

\begin{tabular}{|c|c|}
\hline Negatif & A- \\
\hline Y1- & 0 \\
\hline Y2- & 0 \\
\hline Y3- & 0 \\
\hline Y4- & 0 \\
\hline Y5- & 0.21 \\
\hline
\end{tabular}

12. Menghitung jarak dengan solusi ideal positif dan solusi ideal negatif

Pada tahap ini menghitung jarak dengan solusi ideal positif dan negatif setiap alternatif yang ada, berikut hasil menghitung jarak dengan solusi ideal positif dengan solusi ideal negatif.

TABEL $X$

JARAK SOLUSI IDEAL POSITIF DAN SOLUSI IDEAL NEGATIF

\begin{tabular}{|l|c|c|c|}
\hline $\begin{array}{c}\text { Jarak } \\
\text { Alternatif }\end{array}$ & D+ & D- & D++D- \\
\hline A1 & 0.64 & 1.02 & 1.66 \\
\hline A2 & 0.65 & 1.12 & 1.77 \\
\hline A3 & 0.76 & 1.06 & 1.82 \\
\hline A4 & 0.67 & 1.06 & 1.73 \\
\hline A5 & 0.99 & 0.77 & 1.76 \\
\hline A6 & 0.67 & 1.09 & 1.76 \\
\hline A7 & 1.19 & 0.76 & 1.95 \\
\hline A8 & 0.83 & 0.89 & 1.72 \\
\hline A9 & 0.97 & 0.72 & 1.69 \\
\hline A10 & 0.81 & 0.94 & 1.75 \\
\hline A11 & 1.11 & 0.72 & 1.83 \\
\hline A12 & 0.39 & 1.34 & 1.73 \\
\hline A13 & 0.66 & 1.08 & 1.74 \\
\hline A14 & 0.86 & 0.89 & 1.75 \\
\hline A15 & 1.02 & 0.63 & 1.65 \\
\hline A16 & 1.23 & 0.84 & 2.07 \\
\hline A17 & 0.67 & 1.08 & 1.75 \\
\hline A18 & 0.78 & 0.87 & 1.65 \\
\hline A19 & 0.35 & 1.3 & 1.65 \\
\hline A20 & 0.43 & 1.28 & 1.71 \\
\hline A21 & 0.73 & 0.89 & 1.62 \\
\hline A22 & 0.49 & 1.23 & 1.72 \\
\hline A23 & 0.95 & 1.04 & 1.99 \\
\hline & & &
\end{tabular}

13. Menghitung nilai preferensi

Pada tahap ini, dilakukan pencarian nilai kedekatan relatif dari setiap alternatif dengan solusi ideal.

TABEL XI

NILAI PREFERENSI

\begin{tabular}{|c|c|}
\hline Alternatif & $\mathbf{V}$ \\
\hline $\mathrm{A} 1$ & 0.61445783 \\
\hline $\mathrm{A} 2$ & 0.63276836 \\
\hline $\mathrm{A} 3$ & 0.58241758 \\
\hline $\mathrm{A} 4$ & 0.61271676 \\
\hline $\mathrm{A} 5$ & 0.4375 \\
\hline $\mathrm{A} 6$ & 0.61931818 \\
\hline $\mathrm{A} 7$ & 0.38974359 \\
\hline
\end{tabular}

\begin{tabular}{|c|c|}
\hline A8 & 0.51744186 \\
\hline A9 & 0.4260355 \\
\hline A10 & 0.53714286 \\
\hline A11 & 0.39344262 \\
\hline A12 & 0.77456647 \\
\hline A13 & 0.62068966 \\
\hline A14 & 0.50857143 \\
\hline A15 & 0.38181818 \\
\hline A16 & 0.4057971 \\
\hline A17 & 0.61714286 \\
\hline A18 & 0.52727273 \\
\hline A19 & 0.78787879 \\
\hline A20 & 0.74853801 \\
\hline A21 & 0.54938272 \\
\hline A22 & 0.71511628 \\
\hline A23 & 0.52261307 \\
\hline
\end{tabular}

14. Mengurutkan nilai preferensi

Langkah terakhir yaitu mengurutkan nilai kedekatan relatif yang tadi telah dihitung. 5 nilai yang berada pada urutan tertinggi adalah rekomendasi yang akan diberikan

TABEL XII

URUTAN NILAI PREFERENSI

\begin{tabular}{|c|l|c|}
\hline Alternatif & \multicolumn{1}{|c|}{ Objek Wisata } & V \\
\hline A19 & Gunung Srandil & 0.78787879 \\
\hline A12 & Pulau Momongan & 0.77456647 \\
\hline A20 & $\begin{array}{l}\text { Museum Soesilo } \\
\text { Soedarman }\end{array}$ & 0.74853801 \\
\hline A22 & Benteng Karang Bolong & 0.71511628 \\
\hline A2 & Pantai Widarapayung & 0.63276836 \\
\hline
\end{tabular}

15. Hasil implementasi metode TOPSIS pada sistem Berikut hasil dari rekomendasi menggunakan metode TOPSIS pada sistem.

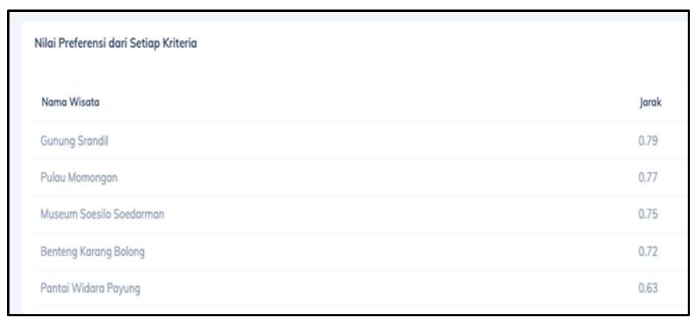

Gambar 6. Hasil Implementasi TOPSIS

\section{B. Hasil Pengujian}

Pengujian Black Box pada penelitian ini dilakukan oleh 48 responden dimana 45 responden sebagai penguji dengan peran wisatawan, dan 3 responden sebagai penguji dengan peran admin. Berikut ini merupakan hasil dari pengujian menggunakan metode Black Box yang dilakukan oleh 45 responden sebagai wisatawan: 
TABEL XIII

DAFTAR UII WISATAWAN

\begin{tabular}{|c|c|c|c|}
\hline \multirow[t]{2}{*}{ No } & \multirow[t]{2}{*}{ Pertanyaan } & \multicolumn{2}{|c|}{ Pertanyaan } \\
\hline & & Sesuai & Tidak \\
\hline 1 & $\begin{array}{l}\text { Saya dapat mengakses } \\
\text { situs web } \\
\text { skripsimega.xyz di } \\
\text { perangkat yang saya } \\
\text { gunakan }\end{array}$ & 45 responden & 0 responden \\
\hline 2 & $\begin{array}{l}\text { Jika menu "Wisata" } \\
\text { dipilih maka akan } \\
\text { menampilkan daftar } \\
\text { wisata di Kabupaten } \\
\text { Cilacap }\end{array}$ & 45 responden & 0 responden \\
\hline 3 & $\begin{array}{l}\text { Jika salah satu wisata } \\
\text { dipilih maka akan } \\
\text { menampilkan informasi } \\
\text { tentang wisata }\end{array}$ & 45 responden & 0 responden \\
\hline 4 & $\begin{array}{l}\text { Jika menu "About" } \\
\text { dipilih maka akan } \\
\text { menampilkan informasi } \\
\text { tentang website }\end{array}$ & 45 responden & 0 responden \\
\hline 5 & $\begin{array}{l}\text { Saya dapat melakukan } \\
\text { rekomendasi dengan } \\
\text { cara menginputkan } \\
\text { identitas (nama, email, } \\
\text { kota, nomor HP, lokasi } \\
\text { akan terdeteksi secara } \\
\text { otomatis, jenis wisata, } \\
\text { dan beberapa prioritas) }\end{array}$ & 45 responden & 0 responden \\
\hline 6 & $\begin{array}{l}\text { Saya dapat memberikan } \\
\text { ulasan dan saran pada } \\
\text { halaman "About" }\end{array}$ & 45 responden & 0 responden \\
\hline 7 & $\begin{array}{l}\text { Jika tombol "nama } \\
\text { wisatawan" di tekan, } \\
\text { akan muncul halaman } \\
\text { profil }\end{array}$ & 45 responden & 0 responden \\
\hline 8 & $\begin{array}{l}\text { Saya dapat melakukan } \\
\text { perubahan info } \\
\text { wisatawan pada } \\
\text { halaman profil }\end{array}$ & 45 responden & 0 responden \\
\hline 9 & $\begin{array}{l}\text { Jika menu } \\
\text { "Rekomendasi" pada } \\
\text { halaman profil ditekan, } \\
\text { akan muncul list } \\
\text { rekomendasi yang } \\
\text { sebelumnya telah } \\
\text { didapatkan }\end{array}$ & 45 responden & 0 responden \\
\hline 10 & $\begin{array}{l}\text { Saya dapat melakukan } \\
\text { hapus rekomendasi } \\
\text { pada halaman profil di } \\
\text { menu "Rekomendasi" }\end{array}$ & 45 responden & 0 responden \\
\hline 11 & $\begin{array}{l}\text { Jika menu "Rating" } \\
\text { pada halaman profil } \\
\text { ditekan, akan muncul } \\
\text { list rating yang telah } \\
\text { diinputkan }\end{array}$ & 45 responden & 0 responden \\
\hline 12 & $\begin{array}{l}\text { Saya dapat melakukan } \\
\text { hapus rating pada } \\
\text { halaman profil di menu } \\
\text { "Rating" }\end{array}$ & 45 responden & 0 responden \\
\hline
\end{tabular}

\begin{tabular}{|c|l|c|c|}
\hline 13 & $\begin{array}{l}\text { Saya dapat melakukan } \\
\text { logout pada halaman } \\
\text { profil di menu } \\
\text { "General" }\end{array}$ & 45 responden & 0 responden \\
\hline
\end{tabular}

Berikut ini merupakan hasil dari pengujian menggunakan metode black box yang dilakukan oleh 3 responden sebagai admin:

TABEL XIV

DAFTAR UJI ADMIN

\begin{tabular}{|l|l|c|c|}
\hline No & \multicolumn{1}{|c|}{ Pertanyaan } & \multicolumn{2}{c|}{ Pertanyaan } \\
\cline { 3 - 4 } & & Sesuai & Tidak \\
\hline 1 & $\begin{array}{l}\text { Saya dapat mengakses } \\
\text { situs web } \\
\text { skripsimega.xyz dari } \\
\text { perangkat yang saya } \\
\text { gunakan }\end{array}$ & 3 responden & 0 responden \\
\hline 2 & $\begin{array}{l}\text { Saya dapat mengelola } \\
\text { wisata pada halaman } \\
\text { admin }\end{array}$ & 3 responden & 0 responden \\
\hline 3 & $\begin{array}{l}\text { Saya dapat mengelola } \\
\text { rating wisata pada } \\
\text { halaman admin }\end{array}$ & 3 responden & 0 responden \\
\hline 4 & $\begin{array}{l}\text { Saya dapat mengelola } \\
\text { feedback pada halaman } \\
\text { admin }\end{array}$ & 3 responden & 0 responden \\
\hline 5 & $\begin{array}{l}\text { Saya dapat mengelola } \\
\text { galeri wisata pada } \\
\text { halaman admin }\end{array}$ & 3 responden & 0 responden \\
\hline 6 & $\begin{array}{l}\text { Saya dapat melihat list } \\
\text { dan detail rekomendasi } \\
\text { setiap wisatawan }\end{array}$ & 3 Responden & 0 responden \\
\hline 7 & $\begin{array}{l}\text { Saya dapat menghitung } \\
\text { bobot wisata pada } \\
\text { halaman admin }\end{array}$ & 3 Responden & 0 responden \\
\hline
\end{tabular}

Pengujian keberhasilan rekomendasi dilakukan untuk mengetahui apakah pemberian rekomendasi kepada wisatawan telah sesuai dengan yang diinginkan wisatawan. Berdasarkan data hasil pengujian menggunakan metode Black Box Testing yang dilakukan kepada 48 responden, hasilnya menyatakan bahwa sejumlah 48 responden atau $100 \%$ menyatakan bahwa dari segi fungsional sistem yang dibuat sudah sesuai. Parameter keberhasilan berdasarkan berhasil tidak nya sistem dalam memberikan keluaran yang diinginkan pengguna atau tidak ditemukannya error pada sistem saat pengguna melakukan menggunakan sistem tersebut.

Sebagai contoh salah satu pengguna ketika melakukan pencarian rekomendasi, sistem berhasil menghasilkan list rekomendasi yang dihasilkan oleh masukan pengguna. Dari keberhasilan sistem ini, maka sistem telah berhasil dalam melakukan pemberian rekomendasi. Pada hasil perhitungan yang telah dilakukan, peneliti telah menyamakan nilai yang dimasukkan kedalam sistem dan pada perhitungan yang peneliti lakukan secara manual. Hasil perhitungan yang sistem keluarkan terlihat bahwa terdapat beberapa perbedaan dibagian perhitungan yang menghasilkan angka desimal pada Tabel XII dan Gambar 6. Namun angka tersebut tidak 
mempengaruhi hasil akhir preferensi, yang dimana hasil akhir preferensi tersebut sama antara perhitungan dari sistem dan pada perhitungan yang peneliti lakukan secara manual. Maka dari itu peneliti katakan bahwa sistem telah $100 \%$ berhasil dalam melakukan penerapan metode TOPSIS.

\section{KESIMPULAN}

Berdasarkan pembahasan yang sudah dipaparkan sebelumnya, maka dapat disimpulkan bahwa telah dilakukan perancangan dan pembuatan sistem rekomendasi pemilihan wisata di Kabupaten Cilacap yang menerapkan metode TOPSIS. Selanjutnya hasil yang didapatkan dari pengukuran keberhasilan metode TOPSIS sebesar 100\% dimana memberikan hasil yang sama antara perhitungan sistem dengan perhitungan manual, serta fungsionalitas yang diukur menggunakan metode Black Box sudah sesuai dibuktikan dengan sebanyak 48 responden menyatakan secara fungsional sistem sudah sesuai.

\section{DAfTAR Pustaka}

[1] E. Aprilia and S. Ipnuwati, "Sistem Pendukung Keputusan Pemilihan Wisata Air Terjun Unggulan dengan Menggunakan Metode Topsis di Kabupaten Pesawaran,” Prociding KMSI, 2017, Accessed: Apr. 03, 2021. [Online]. Available: www.stmikpringsewu.ac.id.J.

[2] E. Zuraidah and L. Marlinda, "System Penunjang Keputusan Pemilihan Tempat Wisata Lombok Menggunakan Metode Preference Rangking Organization For Enrichman Evaluation (PROMETHEE)," J. Tek. Komput., vol. 4, no. 1, 2018.

[3] L. Marlinda, "Sistem Pendukung Keputusan Pemilihan Tempat Wisata Yogyakarta Menggunakan Metode ELimination Et Choix Traduisant La RealitA (ELECTRE)," Pros. Semnastek, vol. 0, no. 0,
Nov. 2016, Accessed: Jul. 23, 2021. [Online]. Available: https://jurnal.umj.ac.id/index.php/semnastek/article/view/784.

[4] F. Riandari, P. M. Hasugian, and I. Taufik, "Sistem Pendukung Keputusan Menggunakan Metode Topsis dalam Memilih Kepala Departemen pada Kantor Balai Wilayah Sungai Sumatera II Medan," J. Inform. Pelita Nusant., vol. Vol. 2, no. 1, pp. 6-13, 2017.

[5] A. Indarwasti, B. S. A, and P. G. Kodu, "Sistem Pendukung Keputusan Pemilihan Tempat Kuliner di Depok dengan TOPSIS," Multinetics, vol. 3, no. 1, p. 27, 2017, doi: 10.32722/vol3.no1.2017.pp27-31.

[6] D. Murdiani, A. Yudhana, and S. Sunardi, "Implementasi Agile Method dalam Pengembangan Jurnal Elektronik di Lembaga Penelitian Non Pemerintahan (NGO)," J. Teknol. Inf. dan Ilmu Komput., vol. 7, no. 4, p. 709, Aug. 2020, doi: 10.25126/jtiik.2020741839.

[7] E. Susilo, F. D. Wijaya, and R. Hartanto, "Perancangan dan Evaluasi User Interface Aplikasi Smart Grid Berbasis Mobile Application," 2018. doi: $10.22146 /$ jnteti.v7i2.416.

[8] S. Pratasik and I. Rianto, "Pengembangan Aplikasi E-DUK Dalam Pengelolaan SDM Menggunakan Metode Agile Development," CogITo Smart J., vol. 6, no. 2, pp. 204-216, Dec. 2020, Accessed: Aug. 14, 2021.

[9] I. A. Aziz, B. Setiawan, R. Khanh, G. Nurdiyansyah, and Y. Yulianti, "Jurnal Teknologi Sistem Informasi dan Aplikasi Pengujian Black Box pada Aplikasi Sistem Kasir Berbasis Website Menggunakan Teknik Equivalence Partitions," J. Teknol. Sist. Inf. dan Apl., vol. 3, no. 2, pp. 82-89, Apr. 2020, doi: 10.32493/jtsi.v3i2.4693.

[10] D. A. Kristiyanti, "Penerapan Metode Simple Additive Weighting pada Sistem Pendukung Keputusan Penentuan Beasiswa dan Rekomendasi Magang," JIKA (Jurnal Inform., vol. 5, no. 2, pp. 220 227, Jun. 2021, doi: 10.31000/JIKA.V5I2.4534.

[11] W. S. Kurniasari, U. S. Hardjanto, and A. Diamantina, "Tugas Dinas Pariwisata Dan Kebudayaan Dalam Pengembangan Objek Wisata Di Kabupaten Cilacap,” Diponegoro Law J., vol. 6, no. 2, pp. 1-10, Aug. 2017. 